\title{
Perancangan Aplikasi Peramalan untuk Metode Exponential Smoothing Menggunakan Aplikasi Lazarus (Studi Kasus: Data Konsumsi Listrik Kota Samarinda) Hairi Septiyanor $^{1 *}$, Syaripuddin $^{2}$, Rito Goejantoro ${ }^{3}$ 1,2,3 Jurusan Matematika, Fakultas MIPA, Universitas Mulawarman, Samarinda, Indonesia \\ * Corresponding author, email: hairis232@gmail.com
}

\begin{abstract}
Exponential smoothing is forecasting method used to predict the future. Lazarus is an open source software based on free pascal compiler. at this research, program Lazarus be design use exponential smoothing method to predict electricity consumption data in Samarinda City from September to November 2018. Purposed of this researched is to determine the procedure of building an exponential smoothing forecasting application and obtained forecasting result using the built application. Procedure of built the application are designed interface, designed properties and filled coding. The optimum smoothing parameters were obtained used the golden section method. Based on the analysis, electricity consumption data in Samarinda City shows a trend pattern, then the forecasting was used double exponential smoohting (DES) method are DES Brown and DES Holt. The best forecasting method for at this researched is DES Holt, because DES Holt method produced MAPE 0,0659\% less than DES Brown method produced MAPE 0,0843\%.
\end{abstract}

Keywords: Exponential Smoothing, Electricity Consumption, Golden Section, Lazarus.

\begin{abstract}
Abstrak
Metode exponential smoothing merupakan metode peramalan yang digunakan untuk meramalkan masa yang akan datang. Lazarus adalah suatu software open source yang dibangun berdasarkan compiler free pascal. Pada penelitian ini rancangan program Lazarus untuk metode exponential smoothing meramalkan data konsumsi listrik di Kota Samarinda September 2018 sampai November 2018. Tujuan dari penelitian ini adalah mengetahui tahapan membangun aplikasi peramalan metode exponential smoothing dan memperoleh hasil peramalan menggunakan aplikasi yang dibangun. Tahapan membangun aplikasi adalah merancang interface, merancang property dan mengisi coding. Parameter pemulusan optimum diperoleh menggunakan metode golden section. Berdasarkan hasil analisis, data konsumsi listrik di Kota Samarinda menunjukkan pola trend, kemudian peramalan menggunakan metode double exponential smoothing (DES) yaitu DES Brown dan DES Holt. Metode peramalan yang lebih baik digunakan pada penelitian ini adalah metode DES Holt, karena metode DES Holt menghasilkan nilai MAPE sebesar $0,0659 \%$ yang lebih kecil dibandingkan metode DES Brown menghasilkan nilai MAPE sebesar 0,0843\%.
\end{abstract}

Kata Kunci: Exponential Smoothing, Golden Section, Konsumsi Listrik, Lazarus.

\section{Pendahuluan}

Proses peramalan adalah salah satu unsur yang sangat penting dalam pengambilan keputusan, sebab efektif atau tidaknya suatu keputusan umumnya bergantung pada beberapa faktor yang tidak bisa dilihat pada saat keputusan itu diambil [1]. Definisi dari peramalan adalah memperkirakan besarnya atau jumlah sesuatu pada waktu yang akan

Estimasi: Journal of Statistics and Its Application

e-ISSN: 2721-3803, p-ISSN: 2721-379X

http://journal.unhas.ac.id/index.php/ESTIMASI 
datang berdasarkan data pada masa lampau yang dianalisis secara ilmiah khususnya menggunakan metode statistika [2]. Hasil ramalan yang dibuat sangat tergantung pada metode yang digunakan dalam peramalan tersebut [3]. Beberapa metode peramalan yang umum digunakan yakni metode moving average, exponential smoothing dan autoregressive integrated moving average (ARIMA).

Perkembangan ilmu teknologi banyak membantu dalam perhitungan berbagai macam problematika. Kebutuhan akan peramalan yang efisien mengakibatkan perlunya menggunakan teknologi komputer yang akan mempercepat proses peramalan. Salah satu bentuk dari penggunaan teknologi adalah proses peramalan. Lazarus adalah suatu software open source yang dibangun berdasarkan compiler free pascal. Lazarus menggunakan bahasa pemrograman mudah dan performa yang bagus serta mendukung pengembangan aplikasi yang bersifat visual ataupun non-visual.

Exponential smoothing adalah suatu metode peramalan rata-rata bergerak yang melakukan pembobotan menurun secara eksponensial terhadap nilai observasi. Pengaruh dari metode ini adalah menghilangkan unsur random dalam data sehingga diperoleh suatu pola yang akan berguna dalam meramalkan nilai masa datang. Dalam pemulusan exponential smoothing terdapat satu atau lebih parameter pemulusan yang ditentukan secara eksplisit dan hasil pilihan menentukan bobot yang dikenakan pada nilai observasi [1].

Pada penelitian ini akan dibangun aplikasi metode peramalan menggunakan Lazarus dengan metode exponential smoothing yang akan diaplikasikan pada peramalan penggunaan listrik Kota Samarinda. Aplikasi peramalan metode exponential smoothing yang akan dibuat terdiri dari tiga menu yaitu Single Exponential Smoothing (SES), Double Exponential Smoothing (DES) dan Triple Exponential Smoothing (TES). Berdasarkan uraian yang telah dijelaskan, penelitian ini bertujuan untuk mengetahui tahapan membangun program aplikasi peramalan menggunakan Lazarus, selanjutnya dilakukan peramalan konsumsi listrik di Kota Samarinda menggunakan aplikasi yang dibangun.

\section{Material dan Metode}

Data yang digunakan dalam penelitian ini merupakan data sekunder yaitu konsumsi listrik di Kota Samarinda yang diperoleh dari PLN Kota Samarinda. Data yang diperoleh tersebut akan diolah pada program aplikasi yang dibangun menggunakan Lazarus untuk mendapatkan hasil peramalan dengan metode peramalan exponential smoothing.

\subsection{Exponential Smoothing}

Metode exponential smoothing dilakukan dengan mengulang perhitungan secara terus menerus dengan menggunakan data terbaru, setiap data terbaru diberi bobot yang berbeda untuk data masa lalu dan bobot tersebut mempunyai ciri menurun secara eksponensial. Metode dalam kelompok ini memerlukan adanya penentuan parameter tertentu dan nilai dari parameter terletak antara 0 dan 1 [1]. 
Metode exponential smoothing dibagi menjadi 3 berdasarkan pola data yang terbentuk, yaitu metode SES digunakan untuk data runtun waktu yang bersifat stasioner. Metode DES digunakan untuk data runtun waktu yang membentuk pola trend. Metode TES digunakan untuk data runtun waktu yang membentuk pola musiman.

a. SES

Metode SES digunakan untuk peramalan waktu jangka pendek, biasanya hanya satu bulan kedepan. Model ini mengasumsikan bahwa data berfluktuasi di sekitar ratarata cukup stabil (tidak ada trend atau musiman). Persamaan yang digunakan dalam metode $S E S$ adalah sebagai berikut:

b. DES

$$
F_{t+1}=\alpha X_{t}+(1-\alpha) F_{t}
$$

Metode DES lebih tepat digunakan untuk meramalkan data yang mengalami pola trend. Metode ini dibagi menjadi dua, yaitu:

i. DES Brown

Metode DES Brown menggunakan parameter yang sama untuk dua pemulusan eksponensial yang digunakan. Metode ini menggunakan rumus pemulusan berganda secara langsung, yaitu antara pola trend dan pola lainnya dilakukan secara bersama-sama dengan menggunakan hanya satu parameter. Persamaan yang digunakan dalam metode $D E S$ Brown adalah sebagai berikut:

$$
\begin{gathered}
S_{t}=\alpha X_{t}+(1-\alpha)\left(S_{t-1}+b_{t-1}\right) \\
S_{t}^{\prime \prime}=\alpha S_{t}^{\prime}+(1-\alpha) S_{t-1}^{\prime \prime} \\
\alpha_{t}=2 S_{t}^{\prime}-S_{t}^{\prime \prime} \\
b_{t}=\frac{\alpha}{1-\alpha}\left(S_{t}^{\prime}-S_{t}^{\prime \prime}\right) \\
F_{t+m}=a_{t}+b_{t}(m)
\end{gathered}
$$

ii. DES Holt

Metode DES Holt menggunakan dua parameter berbeda untuk dua pemulusan eksponensial yang digunakan. Metode ini memuluskan pola trend secara terpisah dengan menggunakan parameter yang berbeda dari parameter yang digunakan pada data asli. Persamaan yang digunakan dalam metode DES Holt adalah sebagai berikut:

$$
\begin{gathered}
S_{t}=\alpha X_{t}+(1-\alpha)\left(S_{t-1}+b_{t-1}\right) \\
b_{t}=\gamma\left(S_{t}-S_{t-1}\right)+(1-\gamma) b_{t-1} \\
F_{t+m}=S_{t}+b_{t}(m)
\end{gathered}
$$

c. TES

Metode TES_digunakan ketika data menunjukkan pola musiman. Metode TES dibagi menjadi 2 yaitu:

i. TES Brown 
Metode TES Brown pendekatan dasarnya adalah memasukkan tingkat pemulusan tambahan dan pada peramalannya diberlakukan persamaan kuadratik. Persamaan yang digunakan dalam metode TES Brown adalah sebagai berikut:

$$
\begin{gathered}
S_{t}^{\prime}=\alpha X_{t}+(1-\alpha) S_{t-1}^{\prime} \\
S_{t}^{\prime \prime}=\alpha S_{t}^{\prime}+(1-\alpha) S_{t-1}^{\prime \prime} \\
S_{t}^{\prime \prime \prime}=\alpha S_{t}^{\prime \prime}+(1-\alpha) S_{t-1}^{\prime \prime \prime} \\
\alpha_{t}=3 S_{t}^{\prime}-3 S_{t}^{\prime \prime}+S_{t}^{\prime \prime \prime} \\
b_{t}=\frac{\alpha}{2(1-\alpha)^{2}}\left[(6-5 \alpha) S_{t}^{\prime}-(10-8 \alpha) S_{t}^{\prime \prime}+(4-3 \alpha) S_{t}^{\prime \prime \prime}\right] \\
c_{t}=\frac{\alpha^{2}}{(1-\alpha)^{2}}\left(S_{t}^{\prime}-2 S_{t}^{\prime \prime}+S_{t}^{\prime \prime \prime}\right) \\
F_{t+m}=a_{t}+b_{t}(m)+\frac{1}{2} c_{t}(m)^{2}
\end{gathered}
$$

ii. TES Winters

Metode TES Winters merupakan perluasan dari metode dua parameter dari Holt dengan tambahan satu persamaan untuk mengatasi pola musiman pada data. Metode Winters didasarkan atas tiga persamaan pemulusan, yaitu untuk stasioner, satu untuk trend, dan satu untuk musiman. Persamaan yang digunakan dalam metode TES Winters adalah sebagai berikut:

$$
\begin{gathered}
S_{t}=\alpha \frac{X_{t}}{I_{t-L}}+(1-\alpha)\left(S_{t-1}+b_{t-1}\right) \\
b_{t}=\gamma\left(S_{t}-S_{t-1}\right)+(1-\gamma) b_{t-1} \\
I_{t}=\beta \frac{X_{t}}{S_{t}}+(1-\beta) I_{t-L} \\
F_{t+m}=\left(S_{t}+b_{t}(m)\right) I_{t-L+m}
\end{gathered}
$$

\subsection{Pengukuran Kesalahan Peramalan}

Beberapa metode lebih ditentukan untuk meringkas kesalahan (error) yang dihasilkaan oleh fakta pada teknik peramalan. Sebagian besar dari pengukuran ini melibatkan rata-rata beberapa fungsi dari perbedaan antara nilai aktual dan nilai peramalannya. Persamaan yang digunakan untuk pengukuran kesalahan peramalan adalah sebagai berikut: [1]

$$
\begin{gathered}
M A D=\frac{1}{n} \sum_{t=1}^{n}\left|X_{t}-F_{t}\right| \\
M S E=\frac{1}{n} \sum_{t=1}^{n}\left(X_{t}-F_{t}\right)^{2} \\
M A P E=\frac{1}{n} \sum_{t=1}^{n} \frac{\left|X_{t}-F_{t}\right|}{X_{t}} \times 100 \%
\end{gathered}
$$




\subsection{Golden Section}

Algoritma metode golden section menggunakan prinsip mengurangi daerah batas $x$ yang mungkin menghasilkan nilai MAPE minimum secara iteratif (berulang). Mendapatkan sebuat titik baru yang simetris dibutuhkan nilai $r$ (Golden Ratio) [4]. Pencarian nilai $r$ diperoleh dari rumus yang diilustrasikan oleh Gambar 1.

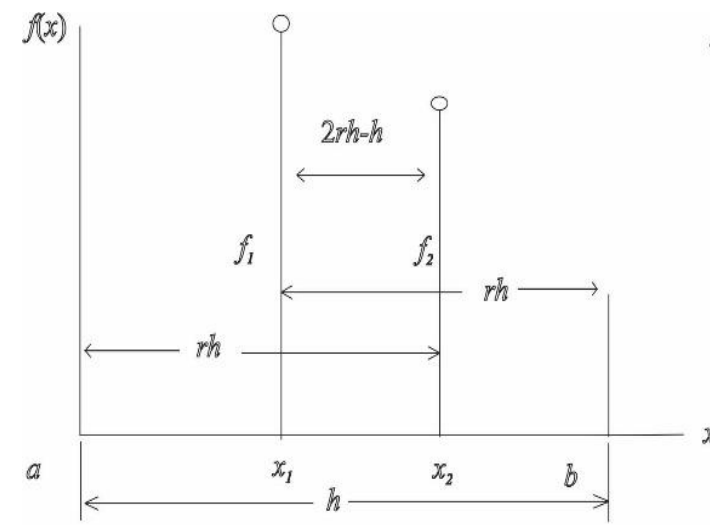

(a)

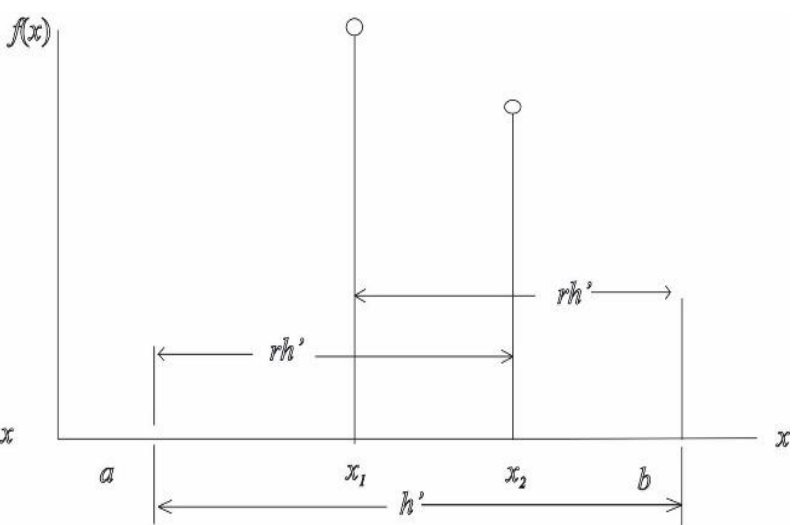

(b)

Gambar 1. Pencarian nilai $r$ yang simetris

Diasumsikan bahwa $f_{1}>f_{2}$ maka $a=x_{1}$ dan $x_{1}=x_{2}$ yang mana akan membuat interval baru $(a, b)$ dari panjang $h^{\prime}=r h$. Tahap operasi selanjutnya dengan menghitung fungsi $x_{2}=a+r h^{\prime}$ dan mengulangi proses tersebut [4].

\subsection{Lazarus}

Lazarus adalah Lingkungan Pengembangan Terpadu (LPT) sumber terbuka bagi pengguna bahasa pemrograman Pascal. Lazarus dibangun di atas kerangka yang juga digunakan untuk menghasilkan aplikasi yang dibuat diatasnya, yaitu Lazarus Component Library $(L C L)$. Sistem adalah sekelompok unsur yang erat hubungannya satu dengan yang lain, yang berfungsi bersama-sama untuk mencapai tujuan tertentu. Sistem mempunyai karakteristik atau sifat-sifat tertentu, yaitu memiliki komponen-komponen, batas sistem, lingkungan sistem, interface, input, output, proses, dan tujuan [5].

Pembuatan program aplikasi Lazarus tidak terlepas dengan jenis data. Pemilihan jenis data yang tepat akan berguna untuk menghemat memori, meningkatkan kecepatan proses dan ketelitian dalam perhitungan [6]. basis data adalah sistem terkomputerisasi yang tujuan utamanya adalah memelihara data yang sudah diolah atau informasi dan membuat informasi tersedia saat dibutuhkan [7]. Data disimpan sedemikian rupa sehingga proses penambahan, pengambilan, dan modifikasi data dapat dilakukan dengan mudah dan terkontrol [8]. 


\section{Hasil dan Diskusi}

\subsection{Rancangan Interface}

Perancangan interface atau tampilan antarmuka merupakan hal yang sangat penting karena menentukan komunikasi antara pengguna dan program. Pada penelitian ini terdapat 5 rancangan interface yaitu form menu utama, form PES, form metode, form grafik, dan form statistika deskriptif. Rancangan interface yang dibuat dalam penelitian ini adalah sebagai berikut:

a. Form menu utama

Form menu utama bertujuan untuk mempersiapkan komponen dan property yang diperlukan saat program PES baru dibuka oleh pengguna. Berikut ini adalah interface form menu utama:

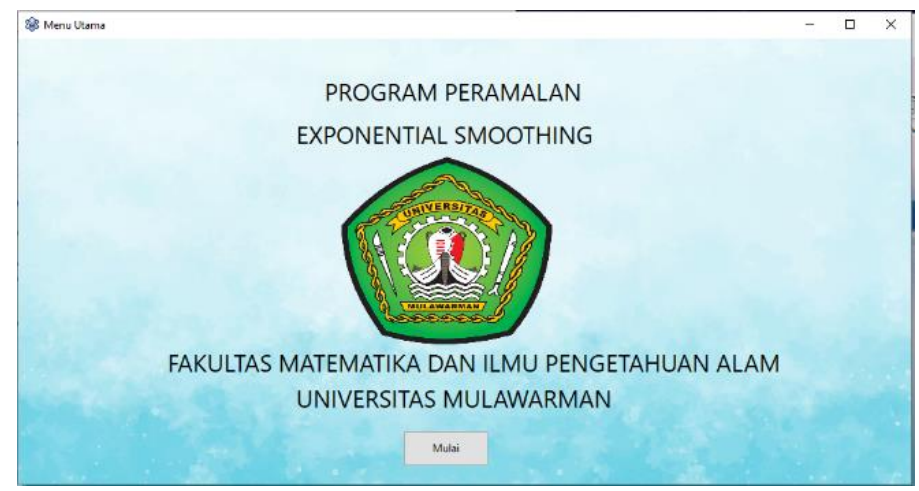

Gambar 2. Form menu utama

\section{b. Form PES}

Form PES merupakan form program inti dalam program Lazarus pada penelitian ini. form PES memuat 2 groupbox dan 4 menu. Berikut ini adalah interface form PES:

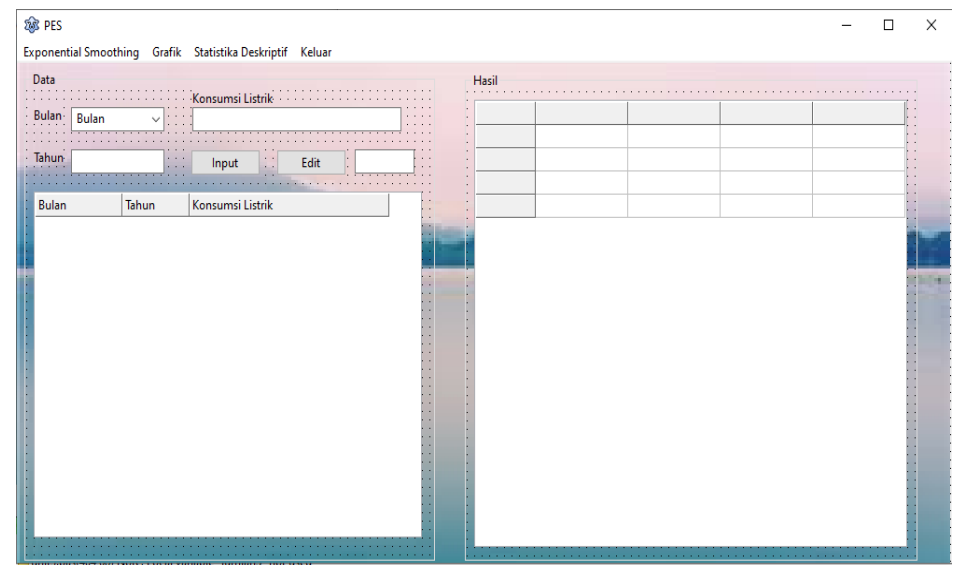

Gambar 3. Form PES 
c. Form metode exponential smoothing

Form metode exponential smoothing memuat 3 groupbox, yaitu groupbox Parameter Pemulusan, groupbox musiman dan groupbox Ramalan.Berikut ini adalah interface form metode exponential smoothing:

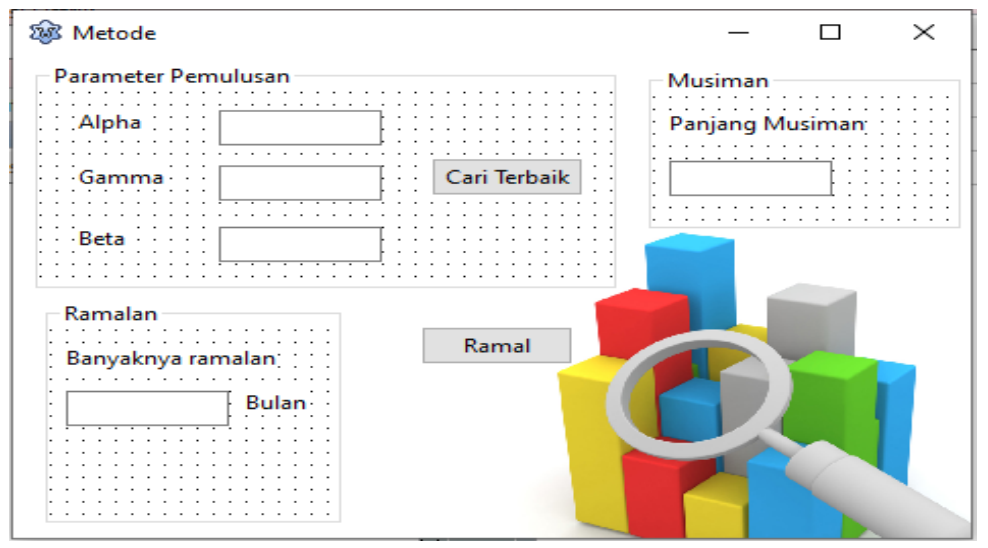

Gambar 4. Form metode exponential smoothing

d. Form grafik

Form grafik digunakan untuk menampilkan grafik time series data dan hasil peramalan. Berikut ini adalah interface form grafik:

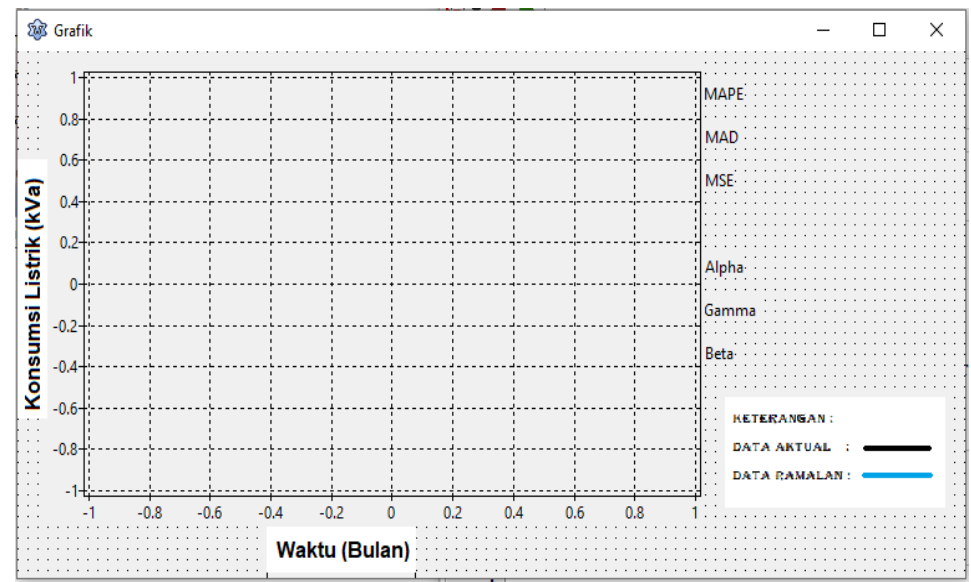

Gambar 5. Form grafik

e. Form statistika deskriptif

Form statistika deskriptif berisi 6 komponen yang menyediakan pilihan hasil statsitika deskriptif yang akan diproses. Berikut ini adalah interface form statistika deskriptif: 


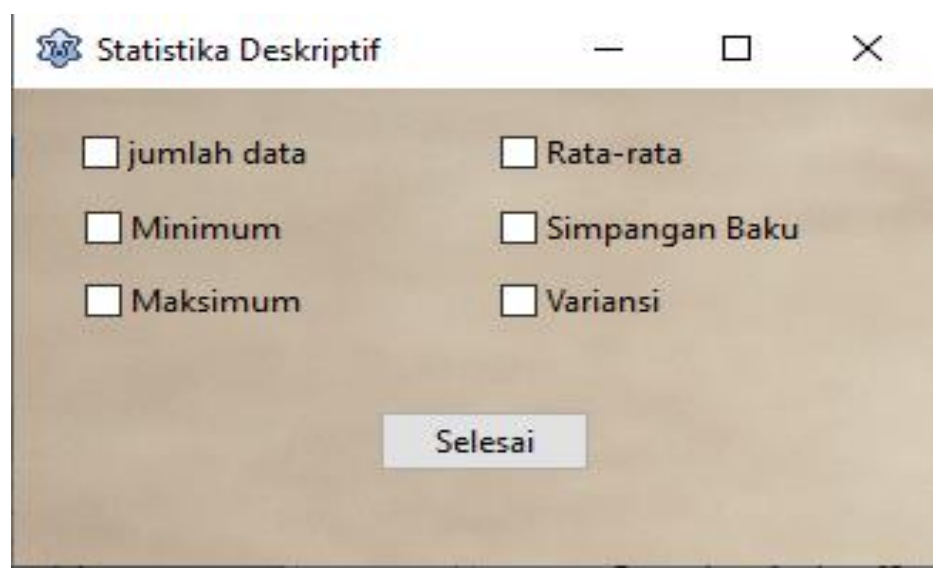

\subsection{Statistika Deskriptif}

Gambar 6. Form statistika deskriptif

Statistika deskriptif untuk mengetahui karakteristik data konsumsi listrik di Kota Samarinda. Karakteristik data konsumsi listrik di Kota Samarinda yang diidentifikasi pada penelitian ini adalah nilai minimum, nilai maksimum, dan nilai rata-rata. Hasil statistika deskriptif yang diperoleh adalah sebagai berikut:

Tabel 1. Hasil statistika deskriptif dari data

\begin{tabular}{|l|l|l|l|}
\hline Variabel & Minimum & Maksimum & Rata-rata \\
\hline Konsumsi Listrik & 382166 & 460637 & 422544.9688 \\
\hline
\end{tabular}

Berdasarkan Tabel 1 terlihat bahwa data konsumsi listrik di Kota Samarinda nilai minimum sebesar $382.166 \mathrm{kVa}$ pada bulan Januari tahun 2016 dan nilai maksimum sebesar $460.637 \mathrm{kVa}$ pada bulan Agustus tahun 2018 dengan nilai rata-rata sebesar $422.544,9688$.

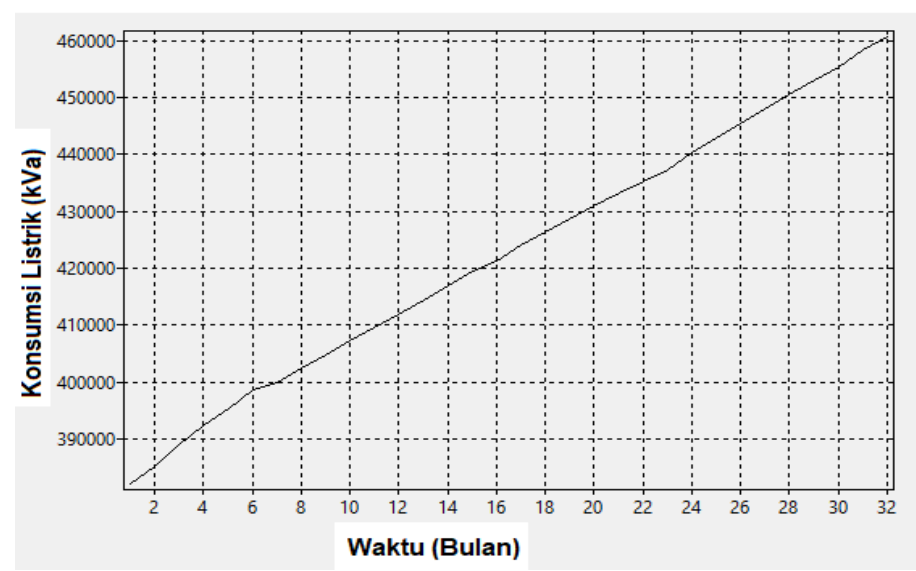

Gambar 7. Time series plot data konsumsi listrik 
Berdasarkan Gambar 7 diketahui bahwa data konsumsi listrik terendah terjadi pada bulan Januari tahun 2016 dan tertinggi terjadi pada bulan Agustus tahun 2018. Data konsumsi listrik naik secara perlahan memperlihatkan bahwa time series plot memiliki pola trend naik. Oleh karena itu data konsumsi listrik di Kota Samarinda dapat diramalkan menggunakan metode DES Brown dan DES Holt.

\subsection{DES Brown}

$D E S$ Brown dalam penelitian ini pemilihan parameter pemulusan $\alpha$ terbaik adalah dengan menggunakan metode golden section. Hasil dari proses metode golden section untuk metode DES Brown adalah sebagai berikut:

\begin{tabular}{|c|c|c|c|c|c|c|c|c|}
\hline \multicolumn{9}{|l|}{ Hasil } \\
\hline Iterasi ke- & Alpha 1 & Alpha 2 & MAPE 1 & MAPE 2 & Epsilon & bawah & atas & a \\
\hline 1 & 0.3820 & 0.6180 & 0.1529 & 0.0968 & 0.2360 & 0.0000 & 1.0000 & \\
\hline 2 & 0.6181 & 0.7639 & 0.0968 & 0.0846 & 0.1458 & 0.3820 & 1.0000 & \\
\hline 3 & 0.7640 & 0.8541 & 0.0846 & 0.0854 & 0.0901 & 0.6181 & 1.0000 & \\
\hline 4 & 0.7082 & 0.7640 & 0.0862 & 0.0846 & 0.0558 & 0.6181 & 0.8541 & \\
\hline 5 & 0.7639 & 0.7984 & 0.0846 & 0.0845 & 0.0345 & 0.7082 & 0.8541 & \\
\hline 6 & 0.7984 & 0.8196 & 0.0845 & 0.0848 & 0.0212 & 0.7639 & 0.8541 & \\
\hline 7 & 0.7852 & 0.7983 & 0.0843 & 0.0845 & 0.0131 & 0.7639 & 0.8196 & \\
\hline 8 & 0.7770 & 0.7852 & 0.0844 & 0.0843 & 0.0082 & 0.7639 & 0.7983 & \\
\hline 9 & 0.7851 & 0.7902 & 0.0844 & 0.0843 & 0.0051 & 0.7770 & 0.7983 & \\
\hline 10 & 0.7901 & 0.7933 & 0.0843 & 0.0844 & 0.0032 & 0.7851 & 0.7983 & \\
\hline 11 & 0.7882 & 0.7902 & 0.0843 & 0.0843 & 0.0020 & 0.7851 & 0.7933 & \\
\hline 12 & 0.7870 & 0.7883 & 0.0843 & 0.0843 & 0.0013 & 0.7851 & 0.7902 & \\
\hline 13 & 0.7882 & 0.7890 & 0.0843 & 0.0843 & 0.0008 & 0.7870 & 0.7902 & \\
\hline 14 & 0.7878 & 0.7882 & 0.0843 & 0.0843 & 0.0004 & 0.7870 & 0.7890 & \\
\hline 15 & 0.7883 & 0.7885 & 0.0843 & 0.0843 & 0.0002 & 0.7878 & 0.7890 & \\
\hline 16 & 0.7881 & 0.7882 & 0.0843 & 0.0843 & 0.0001 & 0.7878 & 0.7885 & \\
\hline 17 & 0.7883 & 0.7883 & 0.0843 & 0.0843 & 0.0000 & 0.7881 & 0.7885 & \\
\hline
\end{tabular}

Gambar 8. Hasil proses metode golden section untuk DES Brown

\begin{tabular}{|c|c|c|c|c|c|c|c|c|c|c|c|c|c|}
\hline \multicolumn{14}{|l|}{ Hasil } \\
\hline$t$ & $X_{t}$ & St & SSt & at & bt & $\mathrm{Ft}$ & $t$ & $X_{t}$ & St & SSt & at & bt & $\mathrm{Ft}$ \\
\hline 1 & 382166 & 382166 & 382166 & & & & 17 & 424141 & 423441.49 & 422768.6387 & 424114.350 & 2505.4904 & 423546.3715 \\
\hline 2 & 385206 & 384562.43 & 384055.1073 & 385069.756 & 1889.1073 & & 18 & 426259 & 425662.53 & 425049.8965 & 426275.171 & 2281.2577 & 426619.8410 \\
\hline 3 & 388910 & 387989.61 & 387156.6836 & 388822.556 & 3101.5762 & 386958.8640 & 19 & 428612 & 427987.59 & 427365.6866 & 428609.509 & 2315.7902 & 428556.4295 \\
\hline 4 & 392337 & 391416.65 & 390514.8227 & 392318.496 & 3358.1391 & 391924.1324 & 20 & 431005 & 430366.21 & 429731.0039 & 431001.428 & 2365.3173 & 430925.2997 \\
\hline 5 & 395488 & 394626.09 & 393755.7404 & 395496.454 & 3240.9177 & 395676.6357 & 21 & 433317 & 432692.31 & 432065.4086 & 433319.229 & 2334.4047 & 433366.7454 \\
\hline 6 & 398673 & \begin{tabular}{|l|}
397816.27 \\
\end{tabular} & 396956.6564 & 398675.884 & 3200.9160 & 398737.3718 & 22 & 435266 & 434721.15 & 434158.9309 & \begin{tabular}{|l|l|}
435283.372 \\
\end{tabular} & 2093.5223 & 435653.6341 \\
\hline 7 & 399829 & 399402.90 & 398885.0343 & 399920.776 & 1928.3779 & 401876.8010 & 23 & 437394 & 436828.15 & 436263.0826 & 437393.233 & 2104.1517 & 437376.8949 \\
\hline 8 & 402601 & 401923.96 & 401280.6221 & 402567.304 & 2395.5877 & 401249.1540 & 24 & 440314 & 439576.04 & 438874.6926 & 440277.401 & 2611.6100 & 439497.3851 \\
\hline 9 & 404769 & 404166.70 & 403555.7218 & 404777.689 & 2275.0998 & 404962.8923 & 25 & 442889 & 442187.64 & 441486.2953 & 442889.000 & 2611.6026 & 442889.0119 \\
\hline 10 & 407254 & 406600.41 & 405955.8572 & 407244.982 & 2400.1354 & 407052.7894 & 26 & 445520 & 444814.54 & 444109.9514 & 445519.130 & 2623.6562 & 445500.6032 \\
\hline 11 & 409556 & 408930.30 & 408300.6134 & 409559.994 & 2344.7561 & 409645.1178 & 27 & 447918 & 447260.99 & 446593.9212 & 447928.074 & 2483.9698 & 448142.7868 \\
\hline 12 & 411802 & 411194.06 & 410581.5188 & 411806.604 & 2280.9055 & 411904.7501 & 28 & 450466 & 449787.50 & 449111.4202 & 450463.581 & 2517.4989 & 450412.0441 \\
\hline 13 & 414411 & 413729.97. & 413063.4462 & 414396.502 & 2481.9274 & 414087.5104 & 29 & 453129 & 452421.60 & 451720.8386 & 453122.370 & 2609.4124 & 452981.0808 \\
\hline 14 & 416940 & 416260.43 & 415583.6345 & 416937.240 & 2520.1883 & 416878.4296 & 30 & 455401 & 454770.26 & 454124.6991 & 455415.824 & 2403.8605 & 455731.7892 \\
\hline 15 & 419495 & 418810.24 & 418127.1701 & 419493.316 & 2543.5356 & 419457.4289 & 31 & 458353 & 457594.53 & 456859.9702 & 458329.098 & 2735.2712 & 457819.6854 \\
\hline 16 & 421381 & 420836.77 & 420263.1483 & 421410.393 & 2135.9782 & 422036.8518 & 32 & 460637 & 459992.91 & 459329.6667 & 460656.153 & 2469.6964 & 461064.3697 \\
\hline
\end{tabular}

Gambar 9. Hasil perhitungan metode DES Brown 
Berdasarkan Gambar 8 diketahui bahwa nilai parameter pemulusan $\alpha$ konvergen pada iterasi ke 17. Diperoleh nilai parameter pemulusan $\alpha$ terbaik yaitu sebesar 0,7883 dengan nilai kesalahan peramalan $M A P E$ sebesar $0,0843 \%$. Peramalan menggunakan metode $D E S$ Brown selanjutnya dilakukan dengan menggunakan nilai parameter pemulusan $\alpha$ sebesar 0,7883. Hasil perhitungan metode DES Brown ditunjukkan Gambar 9.

Berdasarkan hasil perhitungan metode DES Brown maka dapat dilakukan peramalan konsumsi listrik di Kota Samarinda untuk 3 bulan yang akan datang. Peramalan dengan menggunakan metode DES Brown adalah sebagai berikut:

a. Ramalan periode $33(m=1)$ yaitu untuk bulan September tahun 2018:

$$
\begin{aligned}
F_{32+1} & =a_{32}+b_{32}(m) \\
F_{33} & =460.656,1534+2.4691,6964(1) \\
& =463.125,8498
\end{aligned}
$$

b. Ramalan periode $34(m=2)$ yaitu untuk bulan Oktober tahun 2018:

$$
\begin{aligned}
F_{32+2} & =a_{32}+b_{32}(m) \\
F_{34} & =460.656,1534+2.4691,6964(2) \\
& =465.751,1501
\end{aligned}
$$

c. Ramalan periode $35(m=3)$ yaitu untuk bulan November tahun 2018:

$$
\begin{aligned}
F_{32+3} & =a_{32}+b_{32}(m) \\
F_{35} & =460.656,1534+2.4691,6964(3) \\
& =468.280,2793
\end{aligned}
$$

\subsection{DES Holt}

DES Holt dalam penelitian ini pemilihan parameter pemulusan $\alpha$ dan $\gamma$ terbaik adalah dengan menggunakan metode golden section. Hasil dari proses metode golden section untuk metode $D E S$ Holt adalah sebagai berikut:

Hasil
\begin{tabular}{|l|l|l|l|l|l|l|l|l|}
\hline Iterasi ke- & Alpha 1 & Alpha 2 & Gamma 1 & Gamma 2 & MAPE $(1,1)$ & MAPE $(1,2)$ & MAPE $(2,1)$ & MAPE $(2,2)$ \\
\hline 1 & 0.3820 & 0.6180 & 0.3820 & 0.6180 & 0.1103 & 0.1046 & 0.0782 & 0.0745 \\
\hline 2 & 0.6181 & 0.7639 & 0.6181 & 0.7639 & 0.0745 & 0.0722 & 0.0666 & 0.0688 \\
\hline 3 & 0.7640 & 0.8541 & 0.5279 & 0.6180 & 0.0675 & 0.0666 & 0.0668 & 0.0677 \\
\hline 4 & 0.7082 & 0.7640 & 0.6180 & 0.6738 & 0.0691 & 0.0681 & 0.0666 & 0.0670 \\
\hline 5 & 0.7639 & 0.7984 & 0.5836 & 0.6181 & 0.0667 & 0.0666 & 0.0664 & 0.0667 \\
\hline 6 & 0.7984 & 0.8196 & 0.5624 & 0.5836 & 0.0662 & 0.0664 & 0.0666 & 0.0668 \\
\hline 7 & 0.7852 & 0.7983 & 0.5492 & 0.5623 & 0.0662 & 0.0661 & 0.0661 & 0.0662 \\
\hline 8 & 0.7983 & 0.8065 & 0.5410 & 0.5492 & 0.0660 & 0.0661 & 0.0661 & 0.0662 \\
\hline 9 & 0.7933 & 0.7984 & 0.5360 & 0.5411 & 0.0660 & 0.0660 & 0.0660 & 0.0660 \\
\hline 10 & 0.7902 & 0.7934 & 0.5410 & 0.5442 & 0.0661 & 0.0660 & 0.0660 & 0.0660 \\
\hline 11 & 0.7933 & 0.7953 & 0.5391 & 0.5411 & 0.0660 & 0.0660 & 0.0659 & 0.0660 \\
\hline 12 & 0.7952 & 0.7965 & 0.5379 & 0.5392 & 0.0659 & 0.0659 & 0.0659 & 0.0660 \\
\hline 13 & 0.7945 & 0.7953 & 0.5372 & 0.5380 & 0.0660 & 0.0660 & 0.0660 & 0.0659 \\
\hline 14 & 0.7953 & 0.7957 & 0.5380 & 0.5384 & 0.0659 & 0.0659 & 0.0659 & 0.0659 \\
\hline 15 & 0.7950 & 0.7952 & 0.5377 & 0.5379 & 0.0660 & 0.0659 & 0.0659 & 0.0659 \\
\hline 16 & 0.7953 & 0.7954 & 0.5380 & 0.5381 & 0.0659 & 0.0659 & 0.0659 & 0.0659 \\
\hline 17 & 0.7955 & 0.7955 & 0.5379 & 0.5379 & 0.0659 & 0.0659 & 0.0659 & 0.0659 \\
\hline$<$ & & & & & & & & \\
\hline
\end{tabular}

Gambar 10. Hasil proses metode golden section untuk DES Holt 
Berdasarkan Gambar 10 diketahui nilai parameter pemulusan $\alpha$ dan $\gamma$ telah konvergen pada iterasi ke 17. Diperoleh nilai parameter pemulusan $\alpha$ optimum sebesar 0,7955 dan nilai parameter pemulusan $\gamma$ optimum sebesar 0,5379 dengan nilai kesalahan peramalan MAPE sebesar 0,0659\%.

Peramalan menggunakan metode DES Holt selanjutnya dilakukan dengan menggunakan nilai parameter pemulusan $\alpha$ sebesar 0,7955 dan $\gamma$ sebesar 0,5379 . Hasil perhitungan metode $D E S$ Holt adalah sebagai berikut:

\begin{tabular}{|c|c|c|c|c|c|c|c|c|c|}
\hline Hasii & & & & & & & & & \\
\hline$t$ & Xt & St & bt & $\mathrm{Ft}$ & $t$ & $x_{t}$ & St & bt & $\mathrm{Ft}$ \\
\hline 1 & 382166 & 382166.0000 & 3040.0000 & & 17 & 424141 & 424066.1521 & 2421.9145 & 423774.9954 \\
\hline 2 & 385206 & 385206.0000 & 3040.0000 & 385206.0000 & 18 & 426259 & 426305.8441 & 2323.8971 & 426488.0666 \\
\hline 3 & 388910 & 388774.2120 & 3324.1252 & 388246.0000 & 19 & 428612 & 428615.6281 & 2316.3056 & 428629.7412 \\
\hline 4 & 392337 & 392288.1935 & 3426.2489 & 392098.3372 & 20 & 431005 & 430990.0579 & 2347.5707 & 430931.9337 \\
\hline 5 & 395488 & 395534.3075 & 3329.3543 & 395714.4424 & 21 & 433317 & 433321.2185 & 2338.7437 & 433337.6286 \\
\hline 6 & 398673 & 398711.9903 & 3247.7703 & 398863.6618 & 22 & 435266 & 435346.5653 & 2170.1675 & 435659.9622 \\
\hline 7 & 399829 & 400264.7405 & 2336.0190 & 401959.7606 & 23 & 437394 & 437419.0988 & 2117.6502 & 437516.7327 \\
\hline 8 & 402601 & 402600.9508 & 2336.1219 & 402600.7595 & 24 & 440314 & 440155.0522 & 2450.2355 & 439536.7490 \\
\hline 9 & 404769 & 404803.3709 & 2264.2037 & 404937.0727 & 25 & 442889 & 442830.9808 & 2571.6358 & 442605.2876 \\
\hline 10 & 407254 & 407215.8760 & 2343.9750 & 407067.5745 & 26 & 445520 & 445495.9951 & 2621.8641 & 445402.6166 \\
\hline 11 & 409556 & 409556.7875 & 2342.3272 & 409559.8510 & 27 & 447918 & 447958.8712 & 2536.3445 & 448117.8592 \\
\hline 12 & 411802 & 411821.8600 & 2300.7718 & 411899.1147 & 28 & 450466 & 450471.9746 & 2523.8431 & 450495.2157 \\
\hline 13 & 414411 & 414352.0287 & 2424.1644 & 414122.6318 & 29 & 453129 & 453101.7642 & 2580.8317 & 452995.8177 \\
\hline 14 & 416940 & 416906.5015 & 2494.2573 & 416776.1931 & 30 & 455401 & 455458.5864 & 2460.3370 & 455682.5959 \\
\hline 15 & 419495 & 419475.7277 & 2534.5831 & 419400.7588 & 31 & 458353 & 458264.2313 & 2646.0781 & 457918.9233 \\
\hline 16 & 421381 & 421509.6940 & 2265.3013 & 422010.3107 & 32 & 460637 & 460692.8918 & 2529.1292 & 460910.3095 \\
\hline
\end{tabular}

Gambar 11. Hasil perhitungan metode DES Holt

Berdasarkan hasil perhitungan metode DES Holt maka dapat dilakukan peramalan konsumsi listrik di Kota Samarinda untuk 3 bulan yang akan datang. Peramalan dengan menggunakan metode DES Holt adalah sebagai berikut:

a. Ramalan periode $33(m=1)$ yaitu untuk bulan September tahun 2018:

$$
\begin{aligned}
F_{32+1} & =S_{32}+b_{32}(m) \\
F_{33} & =460.692,8918+2.529,1292(1) \\
& =463.222,0210
\end{aligned}
$$

b. Ramalan periode $34(m=2)$ yaitu untuk bulan Oktober tahun 2018:

$$
\begin{aligned}
F_{32+2} & =S_{32}+b_{32}(m) \\
F_{34} & =460.692,8918+2.529,1292(2) \\
& =465.751,1501
\end{aligned}
$$

c. Ramalan periode $35(m=3)$ yaitu untuk bulan November tahun 2018:

$$
\begin{aligned}
F_{32+3} & =S_{32}+b_{32}(m) \\
F_{35} & =460.656,1534+2.4691,6964(3) \\
& =468.280,2793
\end{aligned}
$$




\subsection{Perbandingan Metode Peramalan DES Brown dan DES Holt}

Perbandingan metode peramalan dilakukan berdasarkan nilai pengukuran kesalahan peramalan. Metode DES Brown menggunakan a sebesar 0,7883 dan DES Holt menggunakan $\alpha$ sebesar 0,7955 dan $\gamma$ sebesar 0,5379 . Berikut ini adalah perbandingan nilai pengukuran kesalahan peramalan antara metode DES Brown dan DES Holt:

Tabel 2. Perbandingan Metode Peramalan DES Brown dan DES Holt

\begin{tabular}{lccc}
\hline \multirow{2}{*}{ Metode Peramalan } & \multicolumn{3}{c}{ Nilai Pengukuran Kesalahan Peramalan } \\
\cline { 2 - 4 } & $M A P E$ & $M A D$ & $M S E$ \\
\hline$D E S$ Brown & $0,0843 \%$ & 349,4217 & $355.554,7829$ \\
\hline$D E S$ Holt & $0,0659 \%$ & 276,0858 & $224.221,8045$ \\
\hline
\end{tabular}

Berdasarkan Tabel 2, terlihat bahwa metode yang lebih baik digunakan untuk meramalkan data konsumsi listrik di Kota Samarinda yaitu metode DES Holt, karena nilai pengukuran kesalahan peramalan metode DES Holt lebih kecil dibandingkan dengan metode DES Brown.

\subsection{Rancangan Program}

Rancangan program digunakan sebagai penggambaran program secara umum dan acuan untuk tahap perekayasaan. Tahap perekayasaan dapat memudahkan pencarian kesalahan karena komponen dalam keadaan bebas dari komponen lainnya sehingga tidak terjadi persilangan fungsi antar komponen. Suatu komponen yang membutuhkan keterkaitan dengan komponen lainnya maka dapat digunakan rancangan property untuk memudahkan dalam pembuatan. Oleh karena itu, setelah rancangan interface telah jadi maka langkah selanjutnya adalah mengatur property.

Tabel 3. Property Program PES

\begin{tabular}{lcl}
\hline \multicolumn{1}{c}{ Property } & Komponen & \multicolumn{1}{c}{ Fungsi } \\
\hline Background & Picture & Program lebih berwarna dan memiliki label \\
\hline Mulai & Button & memulai program PES \\
\hline Bulan & Combobox & Menginput data bulan \\
\hline Tahun & Edit & Menginput data tahun \\
\hline $\begin{array}{l}\text { Konsumsi } \\
\text { Listrik }\end{array}$ & Edit & Menginput data konsumsi listrik \\
\hline Input & Button & Memproses hasil inputan ke tabel Data \\
\hline Data & Stringgrid & Menampilkan tabel data \\
\hline Hasil & Stringgrid & menampilkan tabel hasil \\
\hline Alpha & Edit & Menginput nilai parameter pemulusan $\alpha$ \\
\hline Gamma & Edit & Menginput nilai parameter pemulusan $\gamma$ \\
\hline Beta & Edit & Menginput nilai parameter pemulusan $\beta$ \\
\hline
\end{tabular}


Perancangan Aplikasi Peramalan Untuk Metode Exponential Smoothing...

Hairi Septiyanor, Syarifuddin, Rito Goejantoro

\begin{tabular}{lcl}
\hline Cari terbaik & Button & $\begin{array}{l}\text { Proses mencari nilai parameter pemulusan optimum } \\
\text { menggunakan metode Golden Section }\end{array}$ \\
\hline $\begin{array}{l}\text { Panjang } \\
\text { musiman }\end{array}$ & Edit & Menginput nilai panjangnya musiman \\
\hline $\begin{array}{l}\text { Banyaknya } \\
\text { ramalan }\end{array}$ & Edit & $\begin{array}{l}\text { Menginput nilai banyaknya ramalan yang } \\
\text { diinginkan }\end{array}$ \\
\hline
\end{tabular}

Tabel 3. Property Program PES (lanjutan)

\begin{tabular}{lcl}
\hline \multicolumn{1}{c}{ Property } & Komponen & \multicolumn{1}{c}{ Fungsi } \\
\hline Ramal & Button & $\begin{array}{l}\text { Memproses perhitungan peramalan menggunakan } \\
\text { metode yang dipilih }\end{array}$ \\
\hline Time series plot & Chart & Menampilkan grafik \\
\hline $\begin{array}{l}\text { Nilai kesalahan } \\
\text { peramalan }\end{array}$ & Label & $\begin{array}{l}\text { Menampilkan nilai kesalahan peramalan yaitu } \\
\text { MAPE, MAD, dan } M S E\end{array}$ \\
\hline $\begin{array}{l}\text { Nilai parameter } \\
\text { pemulusan }\end{array}$ & Label & $\begin{array}{l}\text { Menampilkan nilai parameter pemulusan yaitu } \alpha, \gamma, \\
\text { dan } \beta\end{array}$ \\
\hline Jumlah data & Checkbox & Memilih jumlah data untuk statistika deskriptif \\
\hline Minimum & Checkbox & Memilih minimum untuk statistika deskriptif \\
\hline Maksimum & Checkbox & Memilih maksimum untuk statistika deskriptif \\
\hline Rata-rata & Checkbox & Memilih rata rata untuk statistika deskriptif \\
\hline Simpangan baku & Checkbox & Memilih simpangan baku untuk statistika deskriptif \\
\hline Variansi & Checkbox & Memilih variansi untuk statistika deskriptif \\
\hline Selesai & Button & $\begin{array}{l}\text { Memproses perhitungan statistika deskriptif yang } \\
\text { dipilih }\end{array}$ \\
\hline
\end{tabular}

\section{Kesimpulan}

Perancangan program aplikasi peramalan Lazarus metode Exponential Smoothing terdapat 3 tahap yaitu: pembuatan interface, mengatur property, dan pengisian coding. Terdapat 5 interface yang dibuat yaitu form menu utama, form PES, form metode, form grafik, dan form statistika deskriptif. Pengaturan property yang diperlukan pada bagian input adalah data, nilai parameter pemulusan, panjang musiman, banyaknya ramalan, dan statistika deskriptif. Pengaturan property yang diperlukan pada bagian output adalah hasil nilai parameter pemulusan optimum berdasarkan metode Golden Section, hasil peramalan, time series plot, dan statistika deskriptif.

Hasil Peramalan data konsumsi listrik di Kota Samarinda bulan September 2018 sampai bulan November 2018 menggunakan metode DES Brown dengan nilai $\alpha$ sebesar 0,7883 adalah 463.125,8498 kVa, 465.595,5463 kVa, 468.065,2427 kVa diperoleh nilai MAPE $0,0843 \%, M A D$ 349,4217, dan MSE 355.554,7829 sedangkan dengan menggunakan metode DES Holt dengan nilai $\alpha$ sebesar 0,7955 dan $\gamma$ sebesar 0,5379 
adalah 463.222,0210 kVa, 465.751,1501 kVa, 468.280,2793 kVa diperoleh nilai MAPE 0,0659\%, MAD 276,0858\%, dan MSE 224.221,8045. Metode peramalan yang lebih baik digunakan untuk data konsumsi listrik di Kota Samarinda adalah metode DES Holt, karena metode DES Holt dengan menggunakan nilai $\alpha$ sebesar 0,7955 dan $\gamma$ sebesar 0,5379 memperoleh nilai pengukuran kesalahan peramalan yang lebih kecil dibandingkan dengan metode DES Brown dengan menggunakan nilai $\alpha$ sebesar 0,7883.

\section{Daftar Pustaka}

[1] Makridakis, S., Wheelright, S.C., \& McGee, V.E. Metode dan Aplikasi Peramalan, Jilid 1 Edisi Revisi. Ahli Bahasa: Hari Suminto. Jakarta: Binapura Aksara, 1999.

[2] Sudjana, N. Dasar-dasar Proses Belajar Mengajar. Bandung: Sinarbaru, 1989.

[3] Aswi, \& Sukarna. Analisis Deret Waktu:Teori dan Aplikasi. Makasar: Andira Publisher, 2006.

[4] Kiusalaas, J. Numerical Methods in Engineering with MATLAB. Cambridge: Cambridge University Press, 2005.

[5] Sutabri, Tata. Analisis Sistem Informasi. Yogyakarta: ANDI, 2012.

[6] Enterprise, Jubilee. Pemrograman Visual Basic 6.0. Yogyakarta: Alex Media Komputindo, 2015.

[7] Rosa, A.S. Rekayasa Perangkat Lunak Terstruktur dan Berorientasi Objek. Bandung: Informatika, 2014.

[8] Sutanta, Edhy. Semua Bisa Menjadi Programmer Android-Case Study. Jakarta: PT Elex Media Komputindo, 2011. 